\title{
Introduction to African Americans: Benefits and Challenges of Working at Predominantly White Institutions: Strategies for Thriving
}

\author{
Rudolph Alexander Jr. • Sharon E. Moore
}

Published online: 6 May 2008

(C) Springer Science + Business Media, LLC 2008

\section{Erratum to: J Afr Am St (2008) 12:1-3 \\ DOI: 10.1007/s12111-007-9027-0}

In the original version of the article, the first part of the biographical sketch of Dr. Rudolph Alexander Jr. contained errors. The corrected data are as follows:

Rudolph Alexander, Jr. began his academic career as a criminal justice major, receiving an A.S. degree in criminal justice from Armstrong State College and a B.S. degree in criminology and corrections from Sam Houston State University. Persuaded by his advisor at Sam Houston State University to consider social work, he received a MSW from the University of Houston and later a Ph.D. in social work from the University of Minnesota. In 1989, he was hired as an assistant professor of social work in the College of Social Work at Ohio State University. He was tenured and promoted to associate professor in 1995 and full professor in 2000.

The online version of the original article can be found at http://dx.doi.org/10.1007/s12111-007-9027-0.

R. Alexander Jr. $(\square)$

College of Social Work, Ohio State University, 1947 College Road, Columbus, OH 43210, USA

e-mail: Alexander.2@osu.edu

\section{S. E. Moore}

Raymond A. Kent School of Social Work, University of Louisville, 210 Oppenheimer Hall,

Louisville, KY 40292, USA

e-mail: Semoor02@louisville.edu 